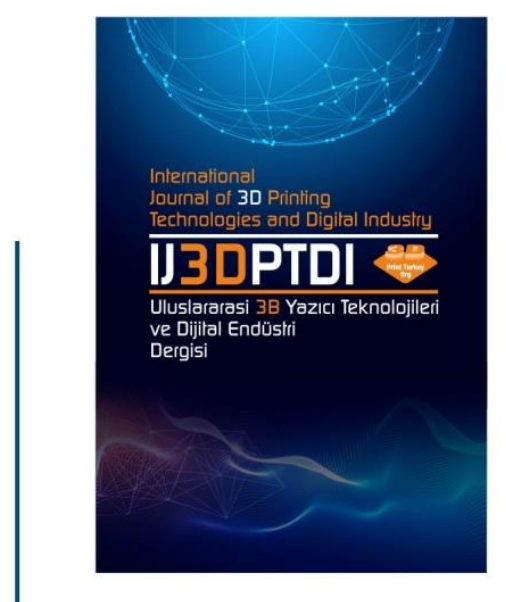

ULUSLARARASI 3B YAZICI TEKNOLOJILERI

VE DIJITAL ENDÜSTRI DERGISI

INTERNATIONAL JOURNAL QF 30 PRINTING TECHNOLOGIES AND DIGITAL INDUSTRY

ISSN:2602-3350 [Online]

URL: https://dergipark.org.tr/ij3dptdi

\title{
RISK PERCEPTION AND DATA MINING IN THE IRON AND STEEL INDUSTRY
}

Yazarlar (Authors): Taner Ersoz ${ }^{(10}$, Bennur Bulut $(\mathbb{D}$

Bu makaleye şu şekilde atıfta bulunabilirsiniz (To cite to this article): Ersoz T., Bulut B., "Risk Perception And Data Mining In The Iron And Steel Industry" Int. J. of 3D Printing Tech. Dig. Ind., 5(2): 313-325, (2021). 


\title{
Risk Perception and Data Mining in the Iron and Steel Industry
}

\author{
Taner Ersöz $z^{a}$ iD $*$ Bennur Bulut ${ }^{b}(i D$ \\ a Karabük University, Faculty of Business, Actuarial Science Department, Karabuk, Turkey \\ ${ }^{\mathrm{b}}$ Karabük University, Faculty of Engineering, Industrial Engineering Department, Karabuk, Turkey \\ *Correponding Author: tanerersoz@karabuk.edu.tr
}

(Received: 28.06.2021; Revised: 07.08.2021; Accepted: 28.08.2021)

\begin{abstract}
Risk is the possibility of threat, that is, potential harm. There may be risks like price fluctuations, exchange rate changes, demand and request changes, and inaccessibility of the material for an enterprise. The biggest mistake is to consider the risk as a possibly harmful circumstance that should only be avoided. When the risk is successfully managed, it empowers the formation of exceptionally imperative vital steps for businesses. Businesses have to show serious patterns to understand, anticipate, prevent, reduce and manage risk correctly and avoid the conceivable loss of life and property. A culture of trust is created in companies that understand the risk correctly and manages it with the right steps. The culture of trust prevents workers from getting distracted, as well as enabling workers to embrace the job and do their job lovingly. Thus, productivity increases in the long run. The purpose of this study is to determine the risk perception of the employees of a firm operating in the iron and steel industry. Possible risks are always high as the enterprise operates as a heavy industry. The questionnaire applied to the employees consists of two parts. The first part consists of demographic features, and the second part consists of questions regarding employees' perceptions of risk. According to the findings which will be obtained with the help of the research, the effect levels of the demographic characteristics of the employees on the employees will be determined and improved findings will be presented to the business management. According to the socio - demographic status of the employees in the enterprise, it is pointed to uncover the risk discernment levels by cluster analysis.
\end{abstract}

Keywords: Perception of risk, risk concept, iron and steel industry, work safety, data mining

\section{INTRODUCTION}

In the 18th and 19th centuries, with the making of new inventions, steam-powered machines came into use. After the first revolution, steam machines were supplanted by electric machines and the invention of vehicles such as automobiles and airplanes took place. The development of technology since 1960 has enabled the third industrial revolution to take place. Transition to the mechanized industry continues with increasing momentum. Today, artificial intelligence, robotics, and 3D printers prepare the ground for the fourth industrial revolution. Many of these technologies, which are also used in the iron and steel industry, have started to show themselves in the sector.

When the crucial developments in the iron and steel industry and the economic development process of the countries are taken under examination, it is seen that the economy plays an important role in the development of sub-sectors related to iron and steel. Companies that want to increase their efficiency and get their share from the developing economy draw a road map for themselves. All these developments are possible with employees working in an environment of trust. However, employees who know the risks in their workplaces and trust where they work can add value to the company they work for. Therefore, the concept of risk should be examined in detail, and whether employees know the risk they are exposed to should be measured.

The concept of risk can be defined as the probability of material and moral losses that an event may cause under certain conditions. In a simple definition, it is said that risk equals potential losses. Hazard refers to the potential for existing or external damage at workplaces that could affect the business and employees. Every potential situation arising from danger is a risk. Identifying and measuring the risk then enables the company to grow optimistically while minimizing pessimistic risks. It is a systematic 
approach that ensures that the company is least affected by all physical risks and financial fluctuations. For this, risk analysis should be done.

Risk is the threats that may occur in return for the ways that the enterprise must follow to survive. It is possible to be protected from these risks or to be affected at least. For this, risks must be managed in a way that positively affects the efficiency and effectiveness of the enterprise. Businesses can get help from internal auditors to manage risk.

The effects of financial mistakes in institutions create negativity for institutions. For this reason, managers today attach importance to Corporate Risk Management (CRM) and internal audit activities. With CRM and internal audit activities, organizations can predetermine and control the risks they may encounter. CRM is a systematic and continuous process that defines the risks that may create a negative situation for the company, keeps the risks at the risk level that the company can handle, and eliminates the situations that prevent the implementation of the strategies determined for the company. CRM not only prevents risks but also enables the business to achieve its goals more efficiently. Thus, it creates a positive image for the institution with a more planned working system.

\section{IRON AND STEEL INDUSTRY IN THE WORLD AND IN TURKEY 2.1 Iron and Steel Industry in The World}

Iron and steel production, which is the main input of durable consumer goods and investment goods, is increasing in developed and developing countries. However, production capacities continue to increase at the same rate. Although the importance of the service and informatics sectors increases with the development of technology, the development levels of the countries can be measured by the iron and steel consumption per capita. Steel, which has a place in many sectors such as automotive, construction, agriculture, and health, continues to maintain its place among the most used metals in the world throughout history. Since the iron and steel industry is linked to many sectors, it is of strategic importance for countries.

\subsection{Iron and Steel Sector in Turkey}

There are three important iron and steel factories in our country. Among these, Kardemir Iron and Steel Factory is Turkey's first national brand in the production of railway tracks. Kardemir, having a capacity of 3.5 million / year and is having 4170 employees according to 2020 data. Erdemir Iron and Steel Factory, located in the Ereğli district of Zonguldak, is a factory that attaches importance to its development and facility that utilizes organic wastes for production as iron and carbon input. It has an important place for the automotive industry with its metal forming laboratory. It has 5230 employees with a capacity of 3.85 million / year. The largest iron and steel factory in Turkey is the İsdemir factory, having 4611 employees and has the only integrated plant that produces long and flat products simultaneously. Turkey is producing 154.4 million tons of steel with three integrated resorts and stands seventh in the world with this production and it is at the leading position in Europe.

\section{RISK CONCEPT}

The improvements made to produce the best steel in the sector with the least cost and to increase the quality continues at an increasing speed day by day. However, it is necessary to give the necessary importance to the occupational health and safety of the employees in this giant sector that affects millions of people around the world. Having departments responsible for occupational health and safety, the employer should not see the work to be done for occupational health and safety as an unnecessary cost, so various ways should be sought to avoid the risks encountered in the sector. 


\subsection{Classification of Risks}

Nowadays, with the increasing institutionalization activities, different risk factors have started to emerge. Risks that may occur in the business are divided into four groups which are strategic, financial, operational, and external environmental risks.

Financial risks: These are the risks that may adversely affect the business financially. These can be credit risk, interest rate risk, or currency risk.

Operation risks: These are the risks that adversely affect the activities of the enterprise and this case causes loss by reducing the efficiency and productivity of the enterprise.

Strategic risks: Structural risks can be caused by the company itself or by the external environment. These are the risks that prevent the organization's goals. A business portfolio can be given as an example of strategic risks.

External environmental risks: These are the risks that may adversely affect the institution due to external factors. It can be given as an example of external environmental risks from natural disasters.

\subsection{Risk Analysis}

There are various risks in all work environments. Accidents caused by risk can lead to loss of life and property. However, it is possible to control the risks by managing them. There are two main approaches to this. One of these is the reactive approach focused on identifying the cause of the accident and seeking a solution to prevent accidents from happening again. The other approach is a proactive system based on estimating the risks before the accident occurs, sorting them according to their importance, reducing these risks, or eliminating them if possible.

\subsection{Assessment of Risks}

Risk assessment is the process of deciding whether or not these risks are acceptable, taking into account the magnitude of risks in any work environment. Today, there are many studies on risk management, and many risk assessment methods are available. These methods can be divided into two main groups in terms of probability of occurrence of risks and estimation of possible effects.

In the qualitative approach, the person who estimates the risk estimates the priorities of the risk based on his views and experiences. The degree of risk is indicated by descriptive expressions such as high or very high instead of numerical data. However, since these evaluations are subjective, the knowledge of the person making it is important in terms of the reliability of the method.

The quantitative approach is made using numerical methods. Numerical values are given to the realization of the risk and the events that will occur as a result. Risk value is found using mathematical and logical methods.

The main purpose of the risk assessment is to decide whether the risk can be accepted. Calculating the probability and severity of the risks does not eliminate the risks. It is necessary to take appropriate measures according to the risks. As a result of the applied risk assessment studies, improvements occur in the work environment. The rate of occupational accidents and occupational diseases is decreasing.

\section{RISK PERCEPTION IN THE IRON AND STEEL INDUSTRY}

Accidents at work are an important problem in Turkey as it causes the deaths of approximately two million people each year in different sectors all over the world. However, occupational accidents cause economic and social losses in addition to the loss of life and create many risks in developed and developing countries. Considering the risks for the iron and steel industry, we are faced with physical risks such as multi-fatal accidents and occupational diseases, as well as various psychological risks. Frequently encountered work accidents: Electric current, fire, burning, explosion/flashing, falling, slipping, collision, accidents caused by work equipment, occupational accidents caused by personal factors. Noise causes hearing loss, vibration carpal tunnel syndrome, dust, and smoke cause asthma. 
When the statistical data are examined, the main reason for the occupational accidents in the iron and steel industry is the accidents that occur due to the wrong or incomplete use of work equipment.

It is very difficult to eliminate all risks for the iron and steel industry. However, it is possible to minimize these risks and manage existing risks. For this purpose, experts of the Common Health Security Unit authorized by the Ministry of Labor and Social Security analyze and report the probabilities of accidents that may occur at workplaces. It works to minimize these risks or to minimize the damages caused by the accident. The risk of a workplace can be in the fields of technical, production, economic, financial, and marketing, and a profit or loss situation arises in the business as a result of the situations arising from these risks. Since internal risks are predictable risks, they can be avoided or their damage can be minimized. External risks, on the other hand, are the risk group that cannot be controlled and are usually related to the market change or government policies. Each employee's perception of risk is different in businesses. The reason for this may be differences such as working conditions, workload, education, the attitude of the employer, physical characteristics, the mood of the working environment, job satisfaction, and gender.

\section{DATA MINING IN THE IRON-STEEL SECTOR}

Developing technology ensures that computer systems are cheap and effective. Data mining is one of the newest technologies used for large data sets today. By processing large amounts of data, it enables the acquisition of meaningful information and the creation of clean data sets. The meaningful results obtained with the data sets created provide information as desired.

Data mining is a way to analyze vast amounts of data created in today's industry to find previously unknown relationships and trends. Before modeling, data from different sources are combined, erroneous data is removed, cleaned, and transformed as necessary. By evaluating processed data with data mining functions and algorithms, it is ensured that meaningful trends, patterns are extracted from the data. Data mining methods in general; the classifier is defined in three basic groups: Predictive, Clustering and Association Rules, and Sequential patterns. Data Mining process: the knowledge discovery in databases can be referred to as a step of the process, which is also called the Decision Support System (KDD) [1]. Information discovery in data mining is given below in Figure 1.

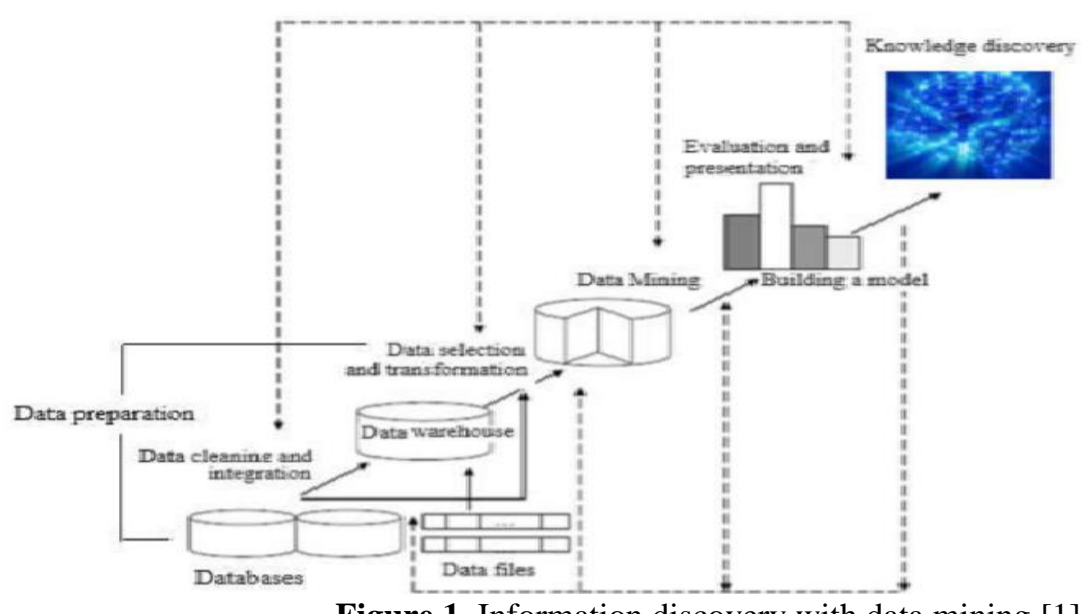

Figure 1. Information discovery with data mining [1].

Data Mining can be examined in six stages [1]. These stages are;

$\checkmark$ Determination of Project Purpose

$\checkmark$ Preparation of Data

- Data Cleaning: Removing noisy and inconsistent data,

- Data Integration: Combining multiple data source (If it is necessary), 
- Data Reduction: Decreasing the size of relevant data by merging, reducing, Compressing, sampling and generalizing,

- Data Transformation: Transforming and consolidating data into appropriate forms for a mining process by performing summary or aggregation operations,

$\checkmark$ Data Mining Modeling, Data Mining: It is an essential process in which intelligent methods are applied in order to extract data patterns.

$\checkmark$ Pattern Evaluation: Identifying the truly interesting patterns representing knowledge based on some interestingness measures.

$\checkmark$ Knowledge Presentation: Using visualization and representation techniques for presenting the mined knowledge to user.

In this study, it is aimed to reveal the risk perception levels of the employees in the business according to their socio-demographic status by clustering analysis. With the cluster analysis, similarities and differences according to the risk perception degrees and the socio-demographic status of the employees have been tried to reveal.

\section{LITERATURE REVIEW}

In the literature review, international articles on risk perception and data mining were examined. In the articles examined, the subjects and how they were handled were examined. Similar studies and different aspects of these studies are discussed.

Mojapelo et al. (2016) revealed the perceptions of employees in the steel industry. The research was conducted with a survey on occupational health and safety of workers in the steel industry in South Africa. Survey sub-dimensions; information and education, health and safety awareness, employee behavior, role of supervisor, health and safety, reporting mechanisms, workplace control and workplace environment. According to the results of the research, it has been seen that safety awareness is the most important dimension among all dimensions for those working in the steel industry. It has been evaluated that managers in the steel industry should consider the results of the study [2].

Parmaksiz's study (2013) was carried out with 80 workers in the 80 iron and steel sector. The factor analysis method was used in this study, which was conducted using the questionnaire technique. These factors are named "Management and Organization", "Occupational Safety and Ergonomic Conditions" and "Work Stress and Motivation". It turned out that the workers are most satisfied with the "Management and Organization" factor. As a result of these satisfaction changes according to education level and status, it was concluded that companies that attach importance to productivity should measure employee satisfaction [3].

Bilgin's study (2016), conducted with 577 participants, discussed how risks during traffic affect driving safety. Correlations between variables were analyzed using the non-parametric spearman method. Whether there is a significant difference between genders in terms of variables was tested by nonparametric Mann-Whitney U analysis. A structural equation model has been established to understand the relations better. According to the model, attitudes play a mediating role in the relationship between risky driving behavior and personality traits. According to the theory, drivers' personality traits also affect their risky driving behaviors. As a result, it was observed that the behaviors of drivers with irritable and anxious personality traits towards traffic safety were more negative and individuals with these characteristics had more risky driving characteristics. After the research and survey results, it was explained what can be done to increase safety in traffic [4].

According to Altunkaynak (2018), most occupational accidents occur in manufacturing. According to the data in 2012, this rate was 56\%. The study, it was aimed to find the causes of such accidents by using data mining and a Chi-Square test. The relationship between Lost Work Days (LWD), Post-Accident Situation (PAS), and Types of Accidents (TA) has been investigated. In the analyzes, it was found that the most common TA was "pressure on the body or members between two objects" and the determinants 
of this were sector, size and age, experience, hours and days. As a result, the incapacity for work was found to be a period of 30-59 days [5].

Oloente et al. (2021) investigated safety and health risks in building construction. In the research, the preventive measures used against health and safety risks were determined and the education level of the employees, the safety and health risks and the level of compliance with the laws and regulations were determined. At the end of the research, it has been determined that the health and safety issues of the employees are not given importance and therefore there are many accidents and health problems [6].

In Ayanoğlu's study (2018), it is determined that the metal sector has the highest accident rate in our country, the number of fatal accidents is less than other sectors in the very dangerous class. Due to the low number of fatal accidents, many accidents and the dangers that cause them are ignored. The accident data set of 165 metal sector workplaces were taken into consideration and transformed into a data set consisting of 192 accidents and 39 variables. After it was understood that the most suitable data mining method was artificial neural networks, a double layer feed-forward accident prediction model Artificial Neural Network was developed by teaching the data set. With the dataset that has been shown to work with $90 \%$ accuracy, it has been revealed that ignored dangers in the metal industry pose a great risk [7].

Çelenk et al. (2020) focused a workplace manufacturing in the 2018 furniture industry. In the method of the study, a risk analysis study was carried out using the L-type Matrix, which is one of the risk assessment decision matrices. As a result of the study, suggestions were made such as giving importance to cleanliness in the work environment, informing employees about occupational safety, and measuring the conditions related to physical factors exposed in the workplace to eliminate and minimize risks [8].

The study of Bilgin and Esen (2018) revealed a detailed examination of the current applications of text mining and machine learning techniques in the field of marketing, especially data mining, and the studies conducted since 2015. Especially in studies conducted after 2015, it is observed that data mining techniques are still used in subjects such as digital marketing, social media-based customer relationship management, the internet of things, and the use of smart systems. It is seen in the studies that not only the purchasing data of the customers are concerned, but also the data is obtained from external data sources [9].

In the study of Farzad (2014), data mining and information discovery methods for predicting workplace models were used in the investigation of accidents in the steel industries. The study analysis accidents at the workplace in the steel industry as well as develops a model to predict future events. Using this model forecasting future events, including method and management, the time of the event, the type of the event, the location of the event, appropriate actions have been sought to prevent serious damage, such as the shift, type of injury, training of the injured person. In this study, Weka software for data mining techniques and related algorithms for linear regression for worker injury were used [10].

In a study by Ecemiş and Irmak (2018), monthly sales figures were determined by matching sales movements in the raw data set with customer information by obtaining more than one hundred thousand sales data between January 2008 and March 2016 from the records of a company operating in the Ecemiş and Irmak stainless steel industry. WEKA software was used to model the data. As a result of the estimation of the sales values calculated by data mining methods, it was decided that the Support Vector Regression method was more successful [11].

Ciarapica and Giacchetta (2009) aimed to evaluate the risk of occupational accidents by considering the probabilities and consequences of injuries that may occur and to determine the general factors that may affect the incidence of injuries. Occupational injuries that occurred in an Italian region (2002-2006) were taken into account in the analyzes. The study aims to demonstrate the flexibility and advantages of using the neuro-fuzzy network, a typical soft computational tool for an occupational injury study, through a real application. Using neuro-fuzzy networks trained with historical data, the possibilities of comparing historical data with the predicted trend in injuries were explored [12].

In Gliowar et al.'s study (2016), it is emphasized that wasted resources create wasted costs in terms of productivity and quality in production. In their study in 2016, demonstrated that a holistic and predictive 
approach should be implemented in their production facilities. By breaking down production facilities at the component level, they provided condition monitoring data, wear data, determination of quality conditions, and prediction of failure moments and quality deviations [13].

Topaloğlu et al.'s (2015) examined the risks posed by blast furnaces in terms of occupational safety in a company and revealed what can be done in terms of all these risks. The causes of work accidents were investigated with the appropriate risk assessment method. Corrective and preventive actions have been determined and it has been explained whether they have been carried out or not. Acceptable and unacceptable risks were determined with 5x5 Matrix Analysis. Hazard and Workability Analysis (HAZOP) has been applied. In addition, it was determined which conditions the employee who had an occupational accident met in terms of OHS. As a result of the studies, it was observed that the number of lost day accidents decreased by $16.7 \%$ in the first 11 months of 2013 compared to the previous year, while the number of injured people decreased by 33.3\%; but the lost working days increased by 184 days [14].

In Güler et al.'s (2018) study, the relationship between place dependency and risk perception was tried to be explained by examining previous national and international studies. Various studies have been carried out on people who must leave their environment due to some risks and want to return there because of their loyalty after a while. As a result of the research, it was concluded that location dependency affects risk perception. Individuals with high place attachment to various types of risk have a stronger risk perception, so there is a correlation between risk perception and place dependency. Individuals with strong place attachment do not think about change when they face risk, they do not care about risks, and thus there is a negative relationship between place dependency and coping with risk [15].

In Comberti et al.'s study (2015), databases created for occupational accidents are widely used for occupational health and safety. Characterizing each employee with many parameters in systematic accident prevention reporting leads to the formation of large data heaps. Many classification and analysis methods have been developed in the last 20 years to find meaningful information from these data heaps used d K-Means and SOM algorithms. With the cluster method they apply, they form a reference that will make decisions at the most critical moments and make corrective decisions for the workplace [16].

In Kocabaş al.'s study (2009), it is defined in the manufacture of metal goods, which are defined as heavy and dangerous works, metallurgy industry, construction works, woodwork, stone works. In this study focusing on ergonomics, OWAS and REBA methods were used. According to the research, employees with the most dangerous working posture are foundry workers in the metallurgy sector, which is in the fourth category with a rate of $22 \%$. When the third and fourth categories are evaluated together, it is determined that there are dangerous working stops in the metal and construction works with a rate of $34 \%$ and in the metallurgy sector with a rate of $32 \%$ [17].

Gül et al.'s study (2016) emphasized that accidents occurring in industries cause great loss of life and property. The reason for work accidents is generally due to not analyzing the safety conditions and working environment was used the K-Means algorithm that aimed to find the relationship between the management of the investment to be made in the workers and the accidents according to the characteristics of the workers. The study realized with 234 occupational accident data, they concluded that data mining is necessary for businesses [18].

In Ersöz's study (2019), it was aimed to define and compare the occupational accidents that occur in the iron and steel sector, to reveal the relationships, and to reveal the independent variables according to the time when the occupational accidents occurred. For this purpose, 2553 occupational accident data were analyzed. The data required for the research consists of data obtained from integrated iron and steel plants and rolling mills. Decision tree algorithms, one of the multivariate statistical methods, were used together with basic statistics as a method in the study. CRT and C5.0 classifier algorithms are used in decision tree algorithms. In the model to be created, the time zone in which the dependent variable occupational accidents occurred was taken. As independent variables in the model; The way the accident 
occurred, the area injured, the task, experience, and age of the employee who had the accident were taken as independent variables [19].

Ersöz et al.'s study 2020, lean production in iron and steel production line, the product produced in the enterprise along the line, and the cycle times related to the process have been calculated. A clearer demonstration of wastes and waiting as progress through the process value stream mapping technique has been used for analysis [20].

\section{MATERIAL AND METHOD}

The study aims to determine the risk discernment of employees in a high-risk factory. For this, a questionnaire was created and applied to the workers working in the metal industry. The research was conducted with 68 workers working in the metal industry. In the survey conducted using the full count method, all the employees were returned to the questionnaire forms. The survey return rate is $100 \%$. As a result of the investigations, no invalid questionnaires were found.

The research was carried out in two stages. In the first stage, a conceptual framework was created with the literature review. In the second stage, after the conceptual framework was formed, the hypotheses were determined based on this framework, the application part was revealed by collecting data with field research. The questionnaire method, one of the quantitative research techniques, was used in this study. The questionnaire form consists of two parts.

In the first part, there are demographic questions regarding gender, age, marital status, education status, profession, and status in the company, service time in the company, working time in the same unit, and the leave periods they have used in the last one year. In the second part, closed-ended questions are consisting of 43 statements in total, prepared with the help of the information obtained as a result of the literature review. The 5-point Likert scale, one of the metrics scale types, was used as the evaluation scale. In the scale, 1 represents "Strongly disagree", 2 "Disagree", 3 "Undecided", 4 "Agree", 5 "Strongly agree". Participants who did not have any idea were separately informed and excluded from the analysis.

Data mining is a statistical process used to reveal data in data warehouses and to make decisions about this data. The data in the questionnaire study, which is made for workers in the metal industry and consists of 43 questions, was modeled using IBM SPSS Modeler Data Mining Program.

In the research, the answers given by the employees to the questions about risk perceptions according to their different demographic characteristics were evaluated. Demographic variables: age, marital status, education level, occupation, status at work, length of service, working time in the same unit and number of leave days used in the last year. In this study, K-Means clustering method was used to determine the similarities and differences in the risk perception levels of the employees in terms of demographic characteristics.

The difference between cluster-based models from classification-based models is that the available data are grouped according to an uncertain class rather than a previously defined classification. For the data to be included in certain groups, it must be subjected to some calculations. These are similarity and distance measurements. In the research, K-Means cluster analysis was performed in data mining clustering methods. The K-Means technique is a fast method used to determine groupings in data. The $\mathrm{K}$ number indicates the number of groups to be created and is determined by the user. The K-means algorithm has four stages [21]:

$\checkmark$ Splitting the data set into two subsets randomly,

$\checkmark$ Calculation of the center point,

$\checkmark$ Evaluating the distance of objects from the center of the cluster and including objects closer to the center of the cluster other than the center of the cluster they are included in the cluster they are close to, 
The center points, which are the average of the clusters that increase with new objects or decrease by exporting objects, are recalculated and the same continues until there is no change in the cluster of objects.

This study is aimed to reveal the similarities and differences regarding the risk perception of employees in a high-risk business in the iron and steel industry. For this purpose, a questionnaire was developed and the questionnaire was applied to all company employees. Also, it is determined the risk perception levels of the employees in the business according to their socio-demographic status by clustering analysis. With the cluster analysis, it has been tried to reveal the similarities and differences according to the risk perception degrees and the socio-demographic status of the employees.

\section{RESULTS}

In the risk perception research conducted for workers in the iron and steel industry, as a result of the analysis made with the K-Means clustering algorithm, it was revealed that the risk perception levels of the employees in the 8th cluster were greatly affected. According to the education level of the employees, it was determined that the risk perception levels of the employees in the 7th cluster were mostly affected by the service period. It has been determined that the employees in the 6th cluster are mostly affected by the situation in the workplace due to their paid and daily wages. In the 9th cluster, it was revealed that the risk perception levels of the employees changed with age. K-Means cluster results are given in Figure 2.

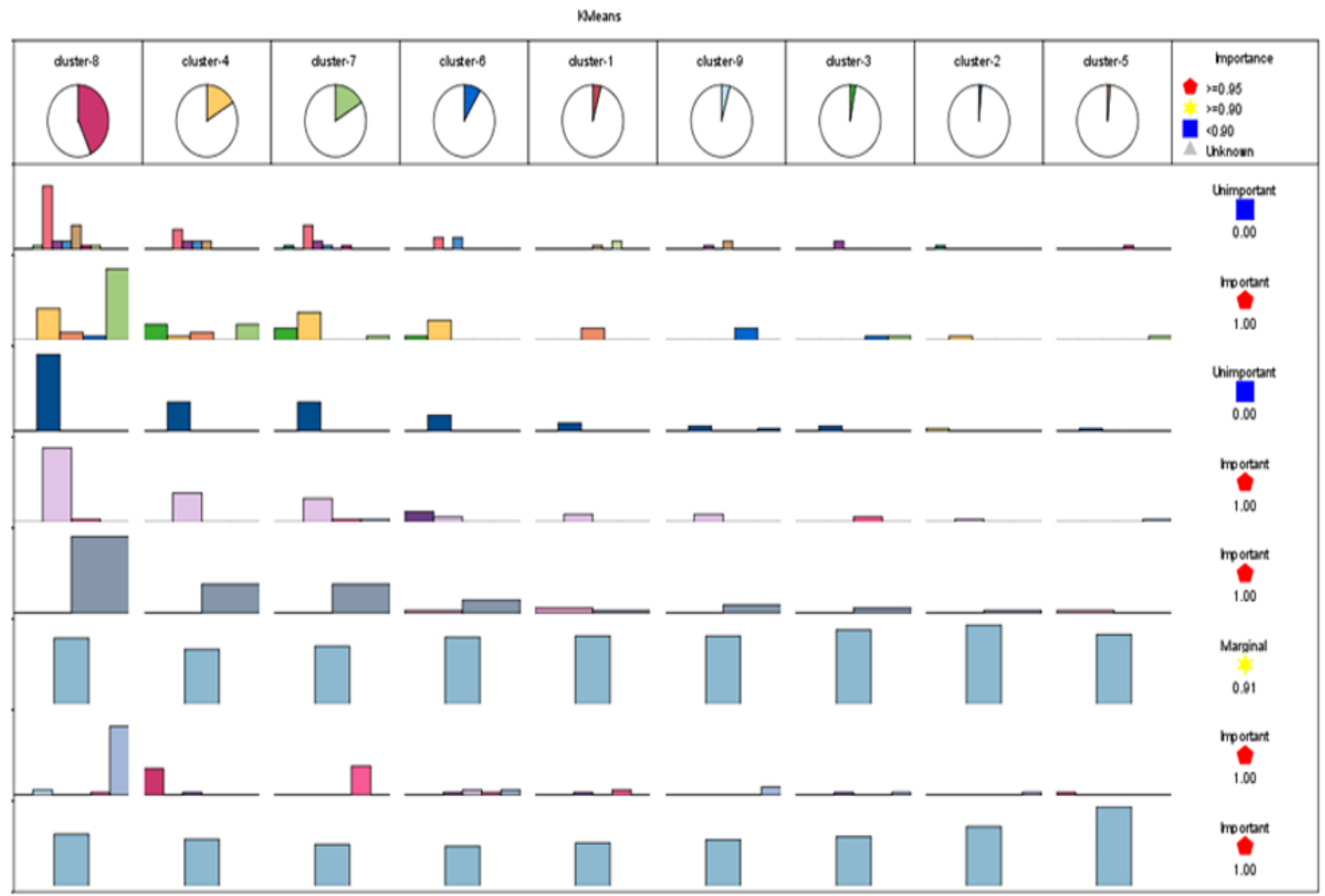

Figure 2. The Result of K-Means

Cluster mean and deviation values according to K-Means clustering results are given in Figure 3. 


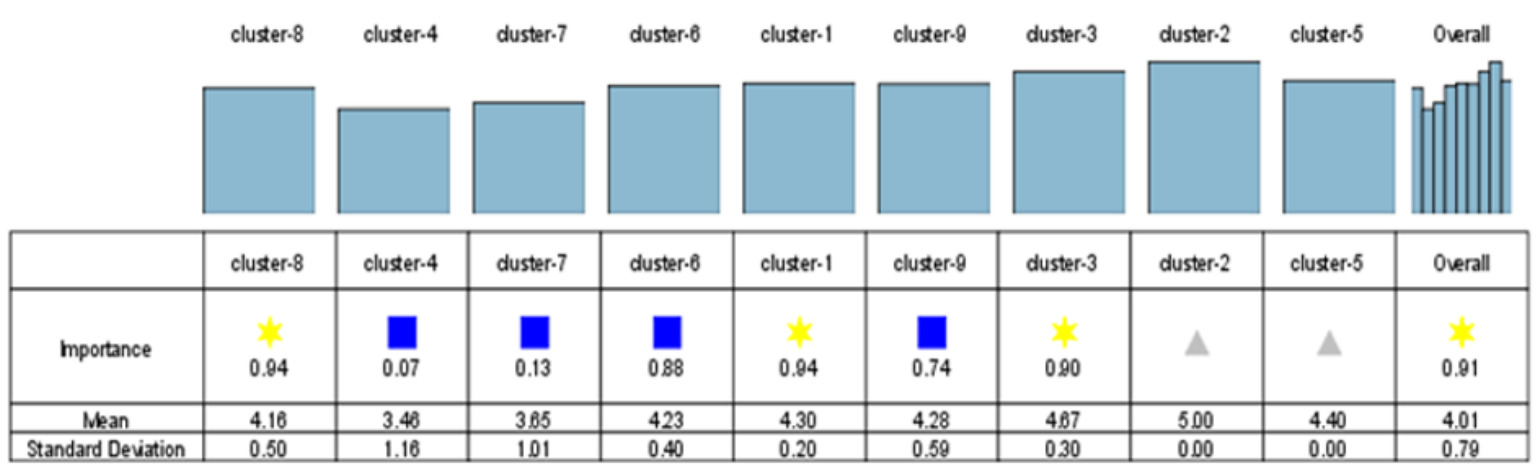

Figure 3. All Clustering Results.

As a result of the research, it was seen that the risk perception of the enterprise was divided into nine clusters and each cluster similarity screenshot and comments are given below.

1st Cluster Results: When the 1st cluster undergraduate and $33.33 \%$ of the high school graduates, the service period is between 11-15 years of wage and casual employees, the marital status is married, $66.67 \%$ It has been determined that the average and deviation value of the risk perception of engineers and $33.33 \%$ of them are workers and $66.67 \%$ of those results are examined in the research; $34-41$ of the working-age group, $66.67 \%$ of the education level is who have taken 18-22 days of leave in the last year are $4.30 \pm 0.19$ and it is "Substantial risk".

2nd Cluster Results: When the results of the 2nd cluster in the study were examined; $50-57$ of the working-age group, $100 \%$ of the education status is undergraduate and literate but has not finished school, the service period is between 6-10 years, the employer position, marital status is married, $100 \%$ of them are workers and in the last 1 year they are all 23 It has been determined that the mean and deviation value of the risk perception of the employees who take more than one day off is $5.00 \pm 0.00$ and it is an "Intolerable risk".

3rd Cluster Results: When the results of the 3rd cluster in the study were examined; The age group of the employee is $42-49,100 \%$ of the education level is a secondary school or equivalent, $50 \%$ of the service period is between 16-20 years, $50 \%$ of them are 21 years and over, salaried and casual employees, marital status is divorced. The mean and deviation value of the risk perception of all employees and 50\% of the employees who took 6-11 days and 50\% of the employees who took 23 days or more in the last 1 year, is $4.67 \pm 0.29$ and it is "Intolerable risk". The clustering result is given in Figure 4.

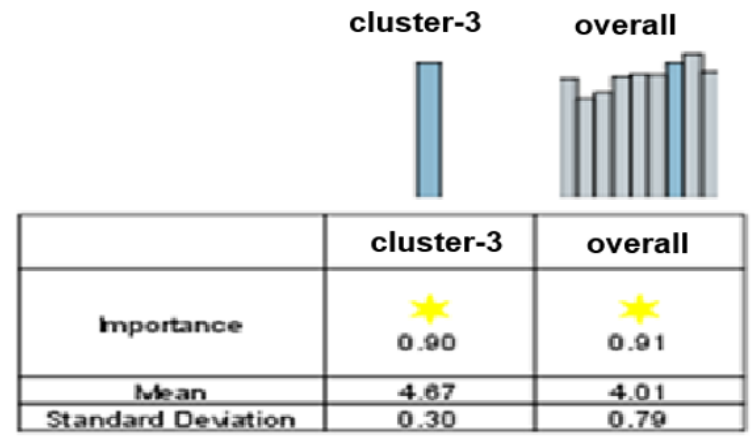

Figure 4. Third Cluster Results.

4th Cluster Results: When the results of the 4th cluster in the study were examined; Working-age group $42-49$, education level $45.45 \%$ primary school, $18.18 \%$ secondary school or equivalent occupation, $18.18 \%$ general high school and $18.18 \%$ high school equivalent occupation, $\%$ of service time $36.36 \%$ 
of them are in the range of $0-5$ years, $9.09 \%$ of them are in the range of $6-10$ years, $18.18 \%$ are in the range of $11-15$ years, $36.36 \%$ of them are 21 years and over, salaried and casual employees. The average and deviation value of the risk perception is $3.45 \pm 1$ of the employees, whose marital status is married, $90.91 \%$ of them are workers and $90.91 \%$ of them have never taken leave in the last 1 year, and $9.09 \%$ of them take 6-11 days off. 3,45 $\pm 1,16$ and was determined to be a "Moderate risk". The clustering result is given in Figure 5.

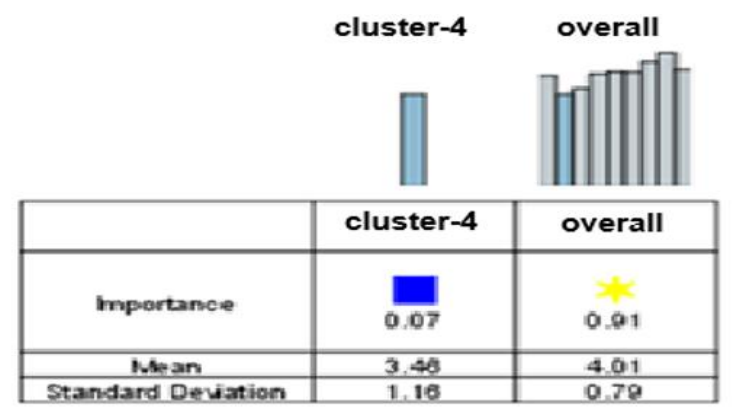

Figure 5. Fourth Cluster Results.

5th Cluster Results: When the 5th cluster results are examined in the research; the average and deviation value of the risk perception of employees who are 65 years and older, education status is undergraduate, the service period is 21 years and above, wage and casual employees, marital status of employees whose marital status has died, engineers and those who have not taken leave in the last 1 year, It was found to be $4.40 \pm 0.00$ and to be "Substantial risk".

6th Cluster Results: When the 6th cluster results are examined in the research; 34-41 of the workingage group, $50 \%$ of the education level of the general high school, $50 \%$ of the primary education, $83.33 \%$ of the service period are between 6-10 years, $16.67 \%$ are between $0-5$ years of wage and casualty employees. $66.67 \%$ of them were single, $33.33 \%$ were married, $83.33 \%$ were engineers and $16.67 \%$ were workers, and $16.67 \%$ in the last 1 year The average and deviation value of the employees who took a leave of $12-17$ days for $33.33 \%, 18-22$ days for $16.67 \%$, and 23 days and more for $33.33 \%$ of the employees' risk perception was $4.22 \pm 0.00$, It has been determined that it is 40 and there is "Substantial risk".

7th Cluster Results: When the 7th cluster results are examined in the research; $34-41$ of the workingage group, $54.55 \%$ of the education level is primary education, $18.18 \%$ is a secondary school or equivalent profession, $9.09 \%$ is generally high school, $27.27 \%$ of the service time is $0-5$ years $63.64 \%$ between 6-10 years, 9.09\% 21 years and over, wage and casual employees, marital status $81.82 \%$ married, 9.09\% divorced, worker and It has been determined that the average and deviation value of the employees who have taken 18-22 days off in the last 1 year regarding risk perception is $3.65 \pm 1.01$ and it is "Substantial risk".

8th Cluster Results: When the 8th cluster results are examined in the research; $42-49$ of the workingage group, $55.17 \%$ of the education level in primary school, $3.45 \%$ in primary school, $6.9 \%$ in high school or equivalent, $6.9 \%$ in high school, $20.69 \%$ in high school. equivalent vocational school, $3.45 \%$ is associate degree and $3.45 \%$ is undergraduate, $27.59 \%$ of service period is between $6-10$ years, $6.9 \%$ is between 11-15 years, 62\%, 07 of them are wage and casual employees for 21 years or more, marital status of $96.55 \%, 3.45 \%$ is divorced, and $6.9 \%$ within the last 1 year is $6-11$ days, $3 \%$, It was determined that the average and deviation value of the risk perception of employees who took leave of 18-22 days for 45 of them and $89.66 \%$ for 23 days and more was $4.16 \pm 0.50$ and it was found to be "Substantial risk". 
9th Cluster Results: When the 9th cluster results are examined in the research; 42-49 of the workingage group, $66.67 \%$ of the education level is high school equivalent vocational school and $33.33 \%$ middle school, $66.67 \%$ of the service period is between $16-20$ years, $33.33 \%$ It has been determined that the average and deviation value of the risk perception of employees whose marital status is married and employed 23 days or more in the last 1 year is $4.27 \pm 0.58$, and it is "Substantial risk".

\section{RESULTS AND RECOMMENDATIONS}

Persistent use of heavy and amazingly huge and perilous materials and machinery, molten metals with temperatures up to 1800 degrees, smoky substances, and noise to which the respiratory system is exposed by air are the most important risks in terms of occupational health and safety. As in other industrial sectors, creating the safety and working environment of the workers in the iron and steel sector, ensuring the welfare and wellbeing of the employees have positive impacts in expanding the proficiency, quality, and coherence of the production.

This study determines the risk perception of the employees of a firm operating in the iron and steel industry. Possible risks are always high as the enterprise operates as a heavy industry. As a result of the analysis made with the K-Means clustering algorithm in the risk perception research conducted for the workers in the enterprise, it has been revealed that the risk perception level of the employees in the 8th cluster is largely affected by the education status of the employees. It has been determined that the risk perception levels of the employees in the 7th cluster are mostly affected by the service period. It was determined that all employees in the 6th cluster were mostly paid and casual employees were mostly affected by the situation at work. In the 9th cluster, it was revealed that the risk understanding level of the employees varies with age. It has been determined that the education level, duration of service, job status, and age are important factors in determining the risk perception level of the workers.

Studies on the risk perception of employees in the iron and steel industry are very important. As a result of the research, the relationship between employee profiles and their perceptions of occupational accidents was revealed. Determined risk perceptions; It is considered that preventing occupational accidents will reduce injuries and deaths by minimizing risks in the iron and steel industry.

\section{REFERENCES}

1. Han, J., Kamber, M., Pei, J., "Data mining: concepts and techniques", Morgan Kaufmann Publishers, San Francisco, Pages 15-25, 2001.

2. Mojapelo, J.M., Mafini, C., "Employee perceptions of occupational health and safety standards in the steel industry”, International Journal of Social Sciences and Humanity Studies, Pages 106-121 2016.

3. Parmaksız, A., Ersöz, T., Özseven, T., Ersöz, F., "Çalışanların iş memnuniyeti, iş stresi ve ergonomik koşullarının değerlendirilmesi”, Gaziosmanpaşa Bilimsel Araştırma Dergisi, Sayfa 82-99, 2013.

4. Bilgin, B., "Ankara'da araç kullanan sürücülerin risk algısı, kişilik ve trafik güvenliği unsurlarına karşı tutumlarının riskli sürüş davranışları-kaza riski üzerine etkisi ile ilgili çalışma", Uzmanlık Tezi, Başkent Üniversitesi, Ankara, 2016.

5. Altunkaynak B., "A statistical study of occupational accidents in the manufacturing industry in Turkey", International Journal of Industrial Ergonomics, Pages 101-109, 2018.

6. Olutende, M., Wamukoya, E.K, Wanzala, M., "Predictors of occupational health and safety managementpractices in the building construction industry, Kakamega", Journal of Nursing and Health Science, Pages 43-57, 2021.

7. Ayanoğlu, C., Kurt, M., "Metal sektöründe veri madenciliği yöntemleri ile bir iş kazası tahmin modeli önerisi”, Ergonomi, Sayfa 78-87, 2019.

8. Çelenk, K.E, Ölmezoğlu, İ.N., “Ahşap ve mobilya imalatı yapan bir işyerinde risklerin belirlenmesi ve örnek risk analiz çalışması”, Gümüşhane Üniversitesi Sağlık Bilimleri Dergisi, Sayfa 25-35, 2020. 
9. Bilgin, E., Esen, F., "Endüstri 4.0 1şı̆̆ında veri madenciliği ve pazarlama: Son gelişmeler, yeni trendler", Sayfa 21-29, 2018.

10. Farzad, G., "Human incidents analysis by knowledge discovery method in a steel maker company", IJISET - International Journal of Innovative Science, Engineering \& Technology, Vol. 1 Issue 5, Pages 327-333, 2014.

11. Ecemiş, O., Irmak, S., "Paslanmaz çelik sektörü satış tahmininde veri madenciliği yöntemlerinin karşılaştırılması”, Kilis 7 Aralık Sosyal Bilimler Dergisi, Sayfa 148-169, 2018.

12. Ciarapica, E.F., Giacchetta, G., "Classification and prediction of occupational injury risk using soft computing techniques: An Italian study”, Safety Science, Pages 36-49, 2009.

13. Glawar, R., Kemeny, Z., Nemeth, T., Matyas, K., Monostori, L., Sihn, W., “A holistic approach to qualityfocused maintenance planning supported by data mining methods”, Procedia CIRP 57, Pages 259-264, 2016.

14. Topaloğlu, G., Koç, A., Yağlı, H., Öztürk, A.N., "Yüksek firınların işletilmesinde risk değerlendirilmesinin yapılması ve geliştirilmesi”, Mühendis ve Makine, Sayfa 55-63, 2015.

15. Güler, İ., Karaçor, K.E., "Yer bağlılı̆̆ı ve risk algısı kavramları arasındaki ilişki”, Düzce Üniversitesi Bilim ve Teknoloji Dergisi, Sayfa 1377-1390, 2018.

16. Comberti, L., Baldissone, G., Demichela, M., "Workplace accidents analysis with a coupled clustering method: SOM and K-means algorithms”, Chemical Engineering Transactions. Pages 1261- 1266, 2015.

17. Kocabaş, M., "Ağır ve tehlikeli işlerde çalışan iş görenlerde zorlanmaya neden olan çalışma duruşlarının analizi”, Yüksek Lisans Tezi, Selçuk Üniversitesi, Konya, 2009.

18. Gül, M., Güneri, A.F., Yılmaz, F., Çelebi, O., "Analysis of the relation between the characteristics of workers and occupational accidents using data mining", The Turkish Journal of Occupational/Environmental Medicine and Safety. Pages 102-118, 2016.

19. Ersöz, T., "Demir çelik sektöründe iş kazalarının analizi”, Sayfa 124, Ekin Yayınevi, Bursa, 2019.

20. Ersöz, T., Sarız, K., Ersöz, F., "Demir-çelik üretim hattında yalın üretim”, Düzce Üniversitesi Bilim ve Teknoloji Dergisi, 8 (1), Sayfa 801-826, 2020.

21. Ersöz, F., "Veri madenciliği teknikleri ve uygulamaları” Sayfa 80-83, Seçkin Yayıncılık, Ankara, 2019. 